Forestry Chronicle

\section{Canadian Institute of Forestry Institut forestier du Canada}

A professional and technical periodical published by the Canadian Institute of Forestry/Institut forestier du Canada to improve the management and use of the Canadian forest land resource and encourage a wider understanding of Forestry.

Périodique bimestriel technique et professionnel publié par l'Institut forestier du Canada dans le but de promouvoir l'amélioration de l'aménagement et de l'utilisation des forêts canadiennes et d'encourager une meilleure compréhension de la foresterie.

Co-Editors/Co-Éditeurs

J.H. Cayford

25 Burnett's Grove Circle.

Nepean, ON K2J IW I

Tel.: (613) $825-6000$

Fax: (613) 825-5932

Dr. D.M. Burgess

R.R. \#1. Beachburg. ON KOJ ICO

Tel: (613) 589-2880 (O)

(613) $582-7129(\mathrm{H})$

Fax: (613) 589-2275

Associate Editors/Editeurs Associés

K.A. Armson - forest soil: J.J. Balatincez - forest products; G.L. Basker ville - silviculture: Roy Shepherd - entomology; F. Bunnell - wildlife Alton S. Harestad - wildife: L. W Carlon - nursery practices: R.A.

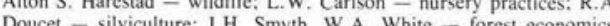
Doucet - silviculture. J.H. Smyth, W.A. White - rorest economics: D.R. Methen - ifre: A. Lavalce pathology: G.M Bonnor - invenV. Sintha - remooe sensing: C.R. Silversides - forest harvesting: V.G. Smith - mensuration: C.J. Sanders - entomology: S. Magnussen

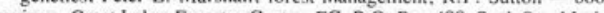
reviews. Great Lakes Forestry Centre. FC. P.O. Box 490, Sault Ste. Marie. ON. P6A 5M7

Production Manager/Directeur à la production

T. Fenton

Suite 1005.

151 Slater St.

Ottawa. Ontario KIP $5 \mathrm{H} 3$

Tel.: (613) $234-2242$

Fax: (613) 234-6181

The Institute assumes no responsibility for the statements and opinion expressed by contributors. There is a page charge of $\$ 90.00$ per page for articles. The Forestr. Chronicle is included in the abstracting and indexin coverage of the Biosciences Information Service of Biological Abstracts coverage of for inclusion in Forestry Abstracts and or Forest Product Abstrocts L'Institut se dégage de toute responsabilité quant aux opinions émises par estry Chronicle" est inclu dans la liste des ouvrages indexés et résumés par le service d'information en Sciences biologiques des "Biological Abstracts" ainsi que celle de la "Environmental Periodicals Bibliography".

Address all correspondence on scientific and technical articles to Dr. D.M Burgess; other editorial correspondence should be addressed to J.H. Cayford.

Le correspondance sur les articles scientifiques et techniques devrait être adressée à M. D.M. Burgess et le reste du courrier. à M. J.H. Cayford.

Address all correspondence concerning address changes and business matter

Toute correspondence d'affaires doit être adressée à

C.A. Lee, Executive Director.

Canadian Institute of Forestry.

Suite 1005, 151 Slater Street.

Ottawa. Ontario. K1P $5 \mathrm{H} 3$.

Tel.: $(613) 234-2242$

Fax: $(613) 234-6181$

Subscription rates per year in Canada $\$ 68.00$ single subseription, $\$ 75.00$ Libraries and Multi-user. All other countries $\$ 80.00$ single subscription $\$ 91.00$ Libraries and Multi-user. Return postage guaranteed. Second Class Mail Registration No. 5714. Single issues last two volumes $\$ 13.60$ each post paid in Canada and \$16.00 to other countries: older ones $\$ 18.00$ each.

Les taux d'abonnement annuel au Canada sont de individuel \$68.00: Bibliothèques et usagers multiples $\$ 75.00$. Tout autre pays: abonnement individual $\$ 80.00$. Bibilothèques et usagers multiples $\$ 91.00$. Retour postal garanti. courrier de deuxième classe, enregistrement no 5714. Le prix par copie datant de moins de deux ans est de Scdn 13.60 port payé au Canad et de $\$ c d n 16.00$ ailleurs. Le prix par copie datant de plus de deux ans es de $\$ c d n 18.00$ port payé toute destination.

Permission to Reprint

Individual readers, and non-profit libraries acting for them, are permitted to make use of the material in this journal for use in teaching or research. For republication, or systematic or multiple reproduction of all material in the journal, permission must be obtained from the Canadian Institute of Forestry/nstitut Forestier du Canada. Quantities of reprints of any iten an be provided by the Institute.

Permission de réimprimer

Chaque lecteur indépendant et toute bibliothèque sans but lucratif agissant pour un lecteur indépendant, peuvent utiliser le contenu de journal à des fins d'enseignement ou de recherche. Pour des tirés à part, ou une reproduction systématique ou multiple de tout le contenu du journal, on doit obtenir la permission de la part du Canadian Institute of Forestry/Institut Forestier du Canada. Des tirés à part sur tout sujet peuvent être obtenus de l'Institut.
Editorial

\section{A Global Forestry Renaissance}

During the past few years we have witnessed a vastly increased awareness of the importance of the world's forest resources. Much of this interest stems from the rapid increase in the rate of tropical deforestation and from threats of climate change, atmospheric pollution and the loss of biodiversity. Recent initiatives on strengthening forestry involve forest research, the upcoming United Nations Conference on Environment and Development and world forestry leadership.

During the past year considerable progress has been made in the establishment of an international forestry research institute. The institute is being established within the Consultative Group on International Agricultural Research (CGIAR) which is an informal association of 40 public and private sector donors who have supported a network of international agricultural research centres. The network is now being expanded to include other natural resources. Funding in 1990 for 16 centres was approximately $\$ 240$ million. Background on this initiative is provided by Ayling in his article in the October issue. Since then there has been a major CGIAR meeting, the 1991 Centres Week, at which time progress towards setting up the forestry research institute was reviewed. The institute will operate in a decentralized manner with its headquarters expected to be in Asia, with satellite offices in Latin America and Africa. Plans are for the Board of Trustees and the Director General to be appointed in early 1992 . The research program will involve management, ecology and conservation of natural forests, germplasm conservation, genetic improvement and plantation establishment, watershed management, utilization and marketing of all forest products and policy and economics.

Meanwhile action continues on the development of a set of guiding principles on the management, conservation and development of forests for consideration and adoption at the forthcoming United Nations Conference on Environment and Development (UNCED). Progress on this activity was reported by Vineberg in the August issue. While it was initially hoped that the Conference would adopt a legally binding convention, it is still anticipated that the statement of principles will eventually evolve into such a convention. A further outcome from UNCED is to be an action plan for the 21 st century - Agenda 21. This plan will include forestry and is expected to deal with such topics as the greening of the world, strengthening research, revitalizing national and international forestry institutions, and promoting industry and trade in products derived from sustainably managed forests.

The need for strengthened leadership in world forestry remains and is discussed in the paper by Roberts, Pringle and Nagel in this issue. While three alternatives are presented, one of which involves the strengthening of world forestry within FAO, it still appears as if there is a need to create a new agency. This was the position adopted by the Institute at its 1990 Annual Meeting when it passed a resolution calling for "the establishment of a separate world forestry organization to be established under the United Nations." A federal interdepartmental committee has since been established to consider this issue; there remains a need for the Institute to consider ways to further promote its resolution so that its chances for implementation may be increased.

Satisfactory progress on these three activities should result in improved conservation and management of the world's forest resources.

J.H. Cayford, R.P.F. 